\title{
A comparison of androgen deprivation therapy versus surgical castration for patients with advanced pros- tatic carcinoma
}

\author{
Yu-hsiang LIN $^{1, \#}$, Chien-lun CHEN ${ }^{1,2, \# \text {, Chen-pang HOU }}{ }^{1}$, Phei-lang CHANG ${ }^{1,2}$, Ke-hung TSUI ${ }^{1,2, *}$ \\ ${ }^{1}$ Department of Urology, Division of Geriatric Urology, Chang Gung Memorial Hospital and Chang Gung University College of Medicine, \\ Taoyuan, Taiwan, China; ${ }^{2}$ Bioinformation Center, Chang Gung Memorial Hospital-Linko, Chang Gung University, Taoyuan, Taiwan, China
}

\begin{abstract}
Aim: To examine the outcomes of patients with advanced prostate carcinoma who underwent medical or surgical castration. Methods: A hundred twenty one consecutive cases of patients with advanced prostate carcinoma who underwent medical or surgical castration between 2001 and 2006 were retrospectively reviewed. Associations between clinical outcomes and prognostic scoring factors were determined based on the Reijke study. In the surgical and medical castration groups, the impact on the prostate-specific antigen (PSA) normalization rate, the rebound rate and the disease-free survival rate were evaluated. The mean follow-up was 36.1 months.

Results: In the initial 12 months, there were no statistical differences in the PSA normalization rate and the PSA rebound rate between the two groups. However, the PSA rebound rate after the 12 th month $(20.90 \%$ vs $40.74 \%, P=0.0175)$ and the 18 th month PSA normalization rate $(59.70 \%$ vs $37.04 \%, P=0.0217)$ differed significantly between the two groups, and these differences were maintained to the end of the study. When comparing patients grouped according to Reijke prognosis scores, there was no difference between medical and surgical castration for the good prognosis group. However, among the patients given a poor prognosis, surgical castration was superior in terms of the PSA normalization rate, the PSA rebound rate, the tumor progression-free survival rate $(P<0.001)$ and the overall survival rate $(P<0.001)$.

Conclusion: Advanced prostate carcinoma patients with poor pretreatment prognosis scores should undergo surgical castration rather than medical castration for better PSA rebound rates and overall survival.
\end{abstract}

Keywords: androgen; surgical castration; prostate neoplasm; metastasis; prognosis; medical castration; prostate-specific antigen; luteinizing hormone-releasing hormone (LHRH)

Acta Pharmacologica Sinica (2011) 32: 537-542; doi: 10.1038/aps.2010.236; published online 14 Mar 2011

\section{Introduction}

Prostate carcinoma is the most common nonskin malignancy among men. Age is acknowledged as one of the risk factors for prostate carcinoma. With prostate-specific antigen (PSA)based screening and postoperative follow-up being widely used $^{[1-3]}$, the incidence of prostate carcinoma has increased. Androgen deprivation therapy (ADT) is a well-established treatment for advanced and metastatic prostate carcinoma, which began with Huggins's observations on advanced and metastatic prostate carcinoma ${ }^{[4]}$. Although ADT improves survival for undergoing hormone therapy, biochemical recurrence after ADT remains a long-term problem to be

\footnotetext{
\# The two authors contributed equally to this work

* To whom correspondence should be addressed.

E-mail khtsui@yahoo.com

Received 2010-07-17 Accepted 2010-12-31
}

solved. The optimal time to initiate hormone therapy for patients with a regular PSA follow-up is still under investigation $^{[3,5,6]}$. As the modern pharmaceutical industry advanced, a luteinizing hormone-releasing hormone (LHRH) agonist with monthly dosing became available. From that point on, surgical castration was largely replaced by medical castration with an LHRH agonist to reduce the psychological impact of orchiectomy to the patients and to preserve reversibility ${ }^{[7,8]}$. Then, maximal androgen blockade (MAB) was proposed to address the androgens of adrenal origin ${ }^{[9]}$. Many trials followed comparing MAB and monotherapy ${ }^{[10-12]}$. However, because of the high cost of LHRH agonist and the limited medical reimbursement system, surgical castration has again become more prevalent ${ }^{[13,14]}$. There are several reports comparing the castration level and the sustainability of surgical and medical castration ${ }^{[7,15,16]}$. However, there are few reports comparing the prognosis between these two groups. 
In this study, we compared the clinical effectiveness of surgical and medical castration with respect to patient outcomes. We also identified clinical outcomes and PSA response features that predicted favorable treatment outcomes for prostate carcinoma after ADT.

\section{Materials and methods Patient selection}

After obtaining institutional review board approval for a retrospective study of the medical records from January 2001 to March 2006, we identified all patients who had advanced prostate carcinoma. Patients with localized prostate carcinoma received definitive therapy, such as radical surgery or radiotherapy. Patients whose clinical staging was greater than tumor stage T3, T4, or metastatic disease, received hormone therapy. In this study, we included these patients receiving hormone therapy but excluded patients on radiotherapy or chemotherapy for prostate carcinoma. However, there were some patients on palliative radiotherapy for spinal or other bone metastases.

The exclusion criteria for this study were concurrent malignancy, previous surgical, radiotherapy or hormonal therapy for prostate carcinoma, poor renal and hepatic function, and a life expectancy of less than 3 months. All of the patients enrolled had a baseline PSA test, chest X-ray films, pelvic magnetic resonance imaging, and whole-body bone scans as baseline data.

From January 2001 to March 2006, we identified 121 patients with advanced prostate carcinoma (defined as stage III or stage IV carcinoma) with complete medical records. MAB included either surgical castration plus antiandrogen therapy with cyproterone (100 mg twice daily), flutamide (250 mg three times per day), or bicalutamide (50 mg daily) or medical castration consisting of LHRH agonist hormone therapy (goserelin $3.6 \mathrm{mg}$ monthly or leuprorelin $14 \mathrm{mg}$ monthly) plus antiandrogen therapy. The patients who received medical castration received antiandrogen 2 weeks in advance for testosterone flare-up prevention ${ }^{[17]}$. All of the prostate tumors were pathologically staged according to the 1997 TNM classification.

Reijke $^{[18]}$ developed a prognostic scoring system for patients with advanced prostate carcinoma receiving hormone therapy. The prognostic scoring system is characterized by (a) $>5$ sites of bone metastasis, (b) hydronephrosis, (c) pain requiring analgesics, and (d) alkaline phosphatase $>2$ times the upper limit of the normal range. A prognostic score is determined by counting the parameters present and obtaining a fivelevel score ( $0-4$ points). Collapsing the prognostic score, we divided patients into subgroups according to their prognostic score: the good prognosis group (scores 0 and 1 ) and the poor prognosis group (scores 2, 3, and 4). We further divided the surgical castration (group 1) and medical castration (group 2) patients into good and poor prognostic groups based on Reijke's classification. The four groups were defined as the following: (1) G1g: surgical castration with a good prognosis score, (2) G1p: surgical castration with a poor prognosis score, (3) G2g: medical castration with a good prognosis score, and (4) G2p: medical castration with a poor prognosis score. We evaluated these enrollment criteria in association with subsequent disease progression and treatment patterns to clarify the most appropriate therapy for metastatic prostate carcinoma. After initiating the hormone therapy, patients were monitored regularly with a PSA checkup every 3 months.

\section{Statistical analysis}

SPSS 15.0 for Windows [SPSS INC., CHICAGO, IL60616] was used to analyze the collected data. The PSA normalization rate and the PSA rebound rate were examined using the Chi-squared test. The tumor progression-free survival rate and the overall survival rate were calculated using the KaplanMeier method.

\section{Results}

We identified 121 patients with complete medical records. There were 67 patients in group 1 (surgical castration) and 54 patients in group 2 (medical castration). Table 1 shows the patient distribution and prostate carcinoma characteristics (initial PSA, Gleason score, tumor staging, and metastasis). The bone metastasis rate was higher in the medical castration group, and it reached statistical significance. However, in Reijke's criteria with four independent prognosis factors for advanced prostate carcinoma, there was no difference between these two groups.

The cancer-specific survival rates for patients within group 1 and 2 differed significantly $(P<0.001)$ (Figure 1$)$. Patients in the surgical castration group demonstrated better survival than the medical castration group.

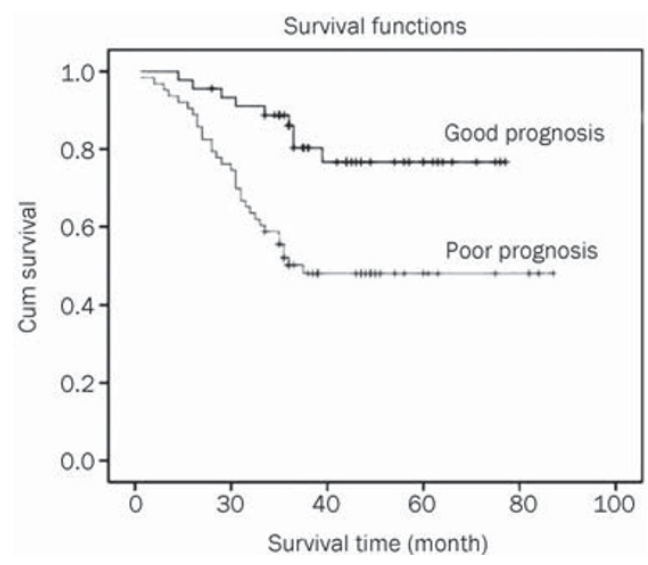

Figure 1. Cancer-specific survival based on overall good and poor prognosis groups.

\section{PSA normalization rate}

The PSA normalization rates by study group are shown in Table 2. We defined the PSA normalization rate as the percentage of patients with a PSA level returning to normal $(<4 \mathrm{ng} / \mathrm{mL})$ and staying normal. The PSA normalization 
Table 1. Patient characteristics of the advanced prostate cancer.

\begin{tabular}{|c|c|c|c|}
\hline & $\begin{array}{l}\text { Group 1: } \\
\text { Orchiectomy + Anti-androgen }\end{array}$ & $\begin{array}{c}\text { Group 2: } \\
\text { LHRH Agonist + Anti-androgen }\end{array}$ & $P$ value \\
\hline Age (mean) & $74.13(59-89)$ & $72.94(50-88)$ & 0.3676 \\
\hline Initial PSA level (median) & $202.82(2.56-13851.20)$ & $297.72(19.14-7422.83)$ & 0.3234 \\
\hline \multicolumn{4}{|l|}{ Gleason score } \\
\hline 7 & 13 & 10 & \\
\hline $7-10$ & 45 & 42 & \\
\hline \multicolumn{4}{|l|}{ TNM stage } \\
\hline Stage III & $17.91 \%(12 / 67)$ & $5.56 \%(3 / 54)$ & \\
\hline Stage IV & $82.09 \%(55 / 67)$ & $94.44 \%(51 / 54)$ & 0.0763 \\
\hline \multicolumn{4}{|l|}{ Metastasis } \\
\hline Bone metastasis & $58.21 \%(39 / 67)$ & $81.48 \%(44 / 54)$ & 0.0109 \\
\hline Lung metastasis & 1 & 3 & \\
\hline Liver metastasis & 0 & 3 & \\
\hline \multicolumn{4}{|l|}{ Reijke prognosis criteria } \\
\hline Good & $45(67.16 \%)$ & $34(62.96 \%)$ & 0.7714 \\
\hline Poor & $22(32.84 \%)$ & $20(37.04 \%)$ & \\
\hline \multicolumn{4}{|l|}{ Anti-androgen } \\
\hline Steroid & $56.9 \%$ & $37.25 \%$ & \\
\hline Non-steroid & $43.1 \%$ & $62.75 \%$ & \\
\hline
\end{tabular}

Table 2. Match comparison of patients undergoing ADT at PSA normalization rate.

\begin{tabular}{|c|c|c|c|c|c|c|c|c|c|}
\hline & Group 1 & Group 2 & $P$-value & Group 1g & Group $2 g$ & $P$-value & Group 1p & Group $2 p$ & $P$-value \\
\hline 3 month & $\begin{array}{l}55.22 \% \\
(37 / 67)\end{array}$ & $\begin{array}{l}44.44 \% \\
(24 / 54)\end{array}$ & 0.3192 & $\begin{array}{l}55.56 \% \\
(25 / 45)\end{array}$ & $\begin{array}{l}47.06 \% \\
(16 / 34)\end{array}$ & 0.6024 & $\begin{array}{l}54.55 \% \\
(12 / 22)\end{array}$ & $\begin{array}{r}40.00 \% \\
(8 / 20)\end{array}$ & 0.3743 \\
\hline 6 month & $\begin{array}{l}71.64 \% \\
(48 / 67)\end{array}$ & $\begin{array}{l}53.70 \% \\
(29 / 54)\end{array}$ & 0.0645 & $\begin{array}{l}75.56 \% \\
(34 / 45)\end{array}$ & $\begin{array}{l}58.82 \% \\
(20 / 34)\end{array}$ & 0.1806 & $\begin{array}{l}63.64 \% \\
(14 / 22)\end{array}$ & $\begin{array}{r}45.00 \% \\
(9 / 20)\end{array}$ & 0.3521 \\
\hline 9 month & $\begin{array}{l}68.66 \% \\
(46 / 67)\end{array}$ & $\begin{array}{l}55.56 \% \\
(30 / 54)\end{array}$ & 0.1960 & $\begin{array}{l}75.56 \% \\
(34 / 45)\end{array}$ & $\begin{array}{l}55.88 \% \\
(19 / 34)\end{array}$ & 0.1094 & $\begin{array}{l}54.55 \% \\
(12 / 22)\end{array}$ & $\begin{array}{l}55.00 \% \\
(11 / 20)\end{array}$ & 1 \\
\hline 12 month & $\begin{array}{l}62.69 \% \\
(42 / 67)\end{array}$ & $\begin{array}{l}42.59 \% \\
(23 / 54)\end{array}$ & 0.0434 & $\begin{array}{l}71.11 \% \\
(32 / 45)\end{array}$ & $\begin{array}{l}47.06 \% \\
(16 / 34)\end{array}$ & 0.0530 & $\begin{array}{l}45.45 \% \\
(10 / 22)\end{array}$ & $\begin{array}{r}35.00 \% \\
(7 / 20)\end{array}$ & 0.5403 \\
\hline 15 month & $\begin{array}{l}61.19 \% \\
(41 / 67)\end{array}$ & $\begin{array}{l}42.59 \% \\
(23 / 54)\end{array}$ & 0.0637 & $\begin{array}{l}66.67 \% \\
(30 / 45)\end{array}$ & $\begin{array}{l}47.06 \% \\
(16 / 34)\end{array}$ & 0.1281 & $\begin{array}{l}50.00 \% \\
(11 / 22)\end{array}$ & $\begin{array}{r}35.00 \% \\
(7 / 20)\end{array}$ & 0.3665 \\
\hline 18 month & $\begin{array}{l}59.70 \% \\
(40 / 67)\end{array}$ & $\begin{array}{l}37.04 \% \\
(20 / 54)\end{array}$ & 0.0217 & $\begin{array}{l}66.67 \% \\
(30 / 45)\end{array}$ & $\begin{array}{l}47.06 \% \\
(16 / 34)\end{array}$ & 0.1281 & $\begin{array}{l}45.45 \% \\
(10 / 22)\end{array}$ & $\begin{array}{r}20.00 \% \\
(4 / 20)\end{array}$ & 0.0375 \\
\hline 21 month & $\begin{array}{l}61.19 \% \\
(41 / 67)\end{array}$ & $\begin{array}{l}35.19 \% \\
(19 / 54)\end{array}$ & 0.0078 & $\begin{array}{l}64.44 \% \\
(29 / 45)\end{array}$ & $\begin{array}{l}44.12 \% \\
(15 / 34)\end{array}$ & 0.1159 & $\begin{array}{l}54.55 \% \\
(12 / 22)\end{array}$ & $\begin{array}{r}20.00 \% \\
(4 / 20)\end{array}$ & 0.0289 \\
\hline 24 month & $\begin{array}{l}55.22 \% \\
(37 / 67)\end{array}$ & $\begin{array}{l}31.48 \% \\
(17 / 54)\end{array}$ & 0.0152 & $\begin{array}{l}64.44 \% \\
(29 / 45)\end{array}$ & $\begin{array}{l}41.17 \% \\
(14 / 34)\end{array}$ & 0.0676 & $\begin{array}{r}36.36 \% \\
(8 / 22)\end{array}$ & $\begin{array}{r}15.00 \% \\
(3 / 20)\end{array}$ & 0.0465 \\
\hline
\end{tabular}

PSA normalization is defined as PSA level $<4 \mathrm{ng} / \mathrm{mL}$

Group 1: Orchiectomy+anti-androgen. Group 2: LHRH agonist+anti-androgen. G1g: surgical castration group with good prognosis score. G1p: surgical castration group with poor prognosis score. G2g: medical castration group with good prognosis score. G2p: medical castration group with poor prognosis score.

rate peaked in the 6th and 9th months in the surgical and the medical castration group, respectively. The PSA normaliza- tion rate then decreased with time; in the 18th month, there was a difference between these two groups $(P=0.0217)$. When 
we further divided groups 1 and 2 into four subgroups by Reijke's ${ }^{[19]}$ prognostic factors, patients with good prognosis scores, regardless of the castration method, showed no significant difference in PSA normalization during the 2 years of follow-up $(P=0.0676)$. However, in the poor prognosis patient group, patients in the surgical castration group (G1p) had significantly better PSA normalization rates than those in the medical castration group $(\mathrm{G} 2 \mathrm{p})(P=0.0465)$. This difference, which occurred after the 18th month, remained to the end of the study.

\section{PSA rebound rate}

After ADT, follow-up was performed every 3 months for the first 2 years. The first detected PSA increase after steady state for all available PSA measurements at least 3 months apart were analyzed for PSA rebound. PSA rebound was defined as a PSA level $\geq 4 \mathrm{ng} / \mathrm{mL}$ or greater than the previous measurement. Table 3 summarizes the PSA rebound rate. The PSA rebound rate was lower in group 1 (surgical castration) than group 2 (medical castration); the significant difference occurred 12 months after castration $(P=0.0175)$. In the good prognosis group, there was no significant difference in the PSA rebound rate between surgical and medical castration until the 21st month. In contrast, in the poor prognosis group, the PSA rebound rate was significantly lower in group 1 (surgical castration) after 15 months than in group 2 (medical castration) $(P=0.0286)$.

\section{Tumor progression-free survival rate}

After stratifying the patients in groups 1 and 2 according to the Reijke scoring system, the cancer survival for patients within the four prognostic groups (G1g, G1p, G2g, and G2p) was analyzed. Tumor progression was defined as any one of the following situations: (1) PSA rebound, (2) increased prog- nosis score, (3) death, (4) imaging or clinical evidence of tumor progression. In the good prognosis group, the curves of tumor progression-free survival were similar between surgical and medical castration $(P=0.001)$. However, in the poor prognosis group, patients in the surgical castration (G1p) group survived significantly longer than those in the medical castration group (G2p) $(P<0.001$, Figure 2).

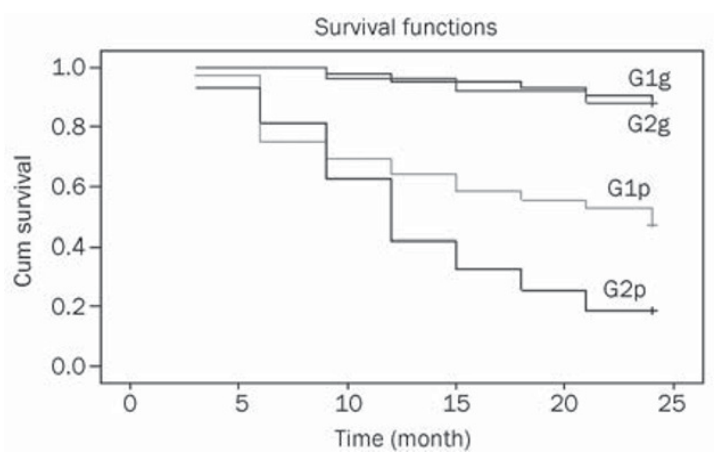

Figure 2. Tumor progression-free survival rate by group.

\section{Overall survival rate}

The overall survival of patients in the four groups is shown in Figure 3. The overall survival rate in the good prognosis group did not differ significantly by castration method. However, among patients with a poor prognosis, those in the surgical castration group survived significantly longer than patients in the medical castration group $(P<0.001)$.

\section{Discussion}

The concept of treating metastatic prostate carcinoma started with Huggins's observation in $1941^{[4]}$. After that, hormone

Table 3. Match comparison of patients undergoing ADT at PSA rebounding rate.

\begin{tabular}{|c|c|c|c|c|c|c|c|c|c|}
\hline & Group 1 & Group 2 & $P$-value & Group 1g & Group 2g & $P$-value & Group 1p & Group $2 p$ & $P$-value \\
\hline 6 month & $\begin{array}{l}8.96 \% \\
(6 / 67)\end{array}$ & $\begin{array}{l}12.96 \% \\
(7 / 54)\end{array}$ & 0.6800 & $\begin{array}{l}4.44 \% \\
(2 / 45)\end{array}$ & $\begin{array}{l}8.82 \% \\
(3 / 34)\end{array}$ & 0.7435 & $\begin{array}{r}18.18 \% \\
(4 / 22)\end{array}$ & $\begin{array}{r}15.00 \% \\
(3 / 20)\end{array}$ & 1 \\
\hline 9 month & $\begin{array}{l}16.42 \% \\
(11 / 67)\end{array}$ & $\begin{array}{l}27.78 \% \\
(15 / 54)\end{array}$ & 0.1971 & $\begin{array}{r}13.33 \% \\
(6 / 45)\end{array}$ & $\begin{array}{l}29.41 \% \\
(10 / 34)\end{array}$ & 0.1394 & $\begin{array}{r}22.72 \% \\
(5 / 22)\end{array}$ & $\begin{array}{r}25.00 \% \\
(5 / 20)\end{array}$ & 1 \\
\hline 12 month & $\begin{array}{l}20.90 \% \\
(14 / 67)\end{array}$ & $\begin{array}{l}40.74 \% \\
(22 / 54)\end{array}$ & 0.0175 & $\begin{array}{r}17.78 \% \\
(8 / 45)\end{array}$ & $\begin{array}{l}35.29 \% \\
(12 / 34)\end{array}$ & 0.1307 & $\begin{array}{r}27.27 \% \\
(6 / 22)\end{array}$ & $\begin{array}{l}50.00 \% \\
(10 / 20)\end{array}$ & 0.2040 \\
\hline 15 month & $\begin{array}{l}22.39 \% \\
(15 / 67)\end{array}$ & $\begin{array}{l}48.15 \% \\
(26 / 54)\end{array}$ & 0.0054 & $\begin{array}{r}20.00 \% \\
(9 / 45)\end{array}$ & $\begin{array}{l}41.18 \% \\
(14 / 34)\end{array}$ & 0.0717 & $\begin{array}{r}27.27 \% \\
(6 / 22)\end{array}$ & $\begin{array}{l}65.00 \% \\
(12 / 20)\end{array}$ & 0.0286 \\
\hline 18 month & $\begin{array}{l}23.88 \% \\
(16 / 67)\end{array}$ & $\begin{array}{l}53.70 \% \\
(29 / 54)\end{array}$ & 0.0014 & $\begin{array}{l}22.22 \% \\
(10 / 45)\end{array}$ & $\begin{array}{l}44.12 \% \\
(15 / 34)\end{array}$ & 0.0676 & $\begin{array}{r}27.27 \% \\
(6 / 22)\end{array}$ & $\begin{array}{l}70.00 \% \\
(14 / 20)\end{array}$ & 0.0124 \\
\hline 21 month & $\begin{array}{l}23.88 \% \\
(16 / 67)\end{array}$ & $\begin{array}{l}57.41 \% \\
(31 / 54)\end{array}$ & 0.0004 & $\begin{array}{l}22.22 \% \\
(10 / 45)\end{array}$ & $\begin{array}{l}47.06 \% \\
(16 / 34)\end{array}$ & 0.0371 & $\begin{array}{r}27.27 \% \\
(6 / 22)\end{array}$ & $\begin{array}{l}75.00 \% \\
(15 / 20)\end{array}$ & 0.0048 \\
\hline 24 month & $\begin{array}{l}25.37 \% \\
(17 / 67)\end{array}$ & $\begin{array}{l}57.41 \% \\
(31 / 54)\end{array}$ & 0.0007 & $\begin{array}{l}22.22 \% \\
(10 / 45)\end{array}$ & $\begin{array}{l}47.06 \% \\
(16 / 34)\end{array}$ & 0.0371 & $\begin{array}{r}31.82 \% \\
(7 / 22)\end{array}$ & $\begin{array}{l}75.00 \% \\
(15 / 20)\end{array}$ & 0.0068 \\
\hline
\end{tabular}

PSA rebound was defined as that PSA level become higher than the previous checked data.

Group 1: Orchiectomy+anti-androgen; Group 2: LHRH agonist+anti-androgen; G1g: surgical castration group with good prognosis score; G1p: surgical castration group with poor prognosis score; G2g: medical castration group with good prognosis score; G2p: medical castration group with poor prognosis score. 


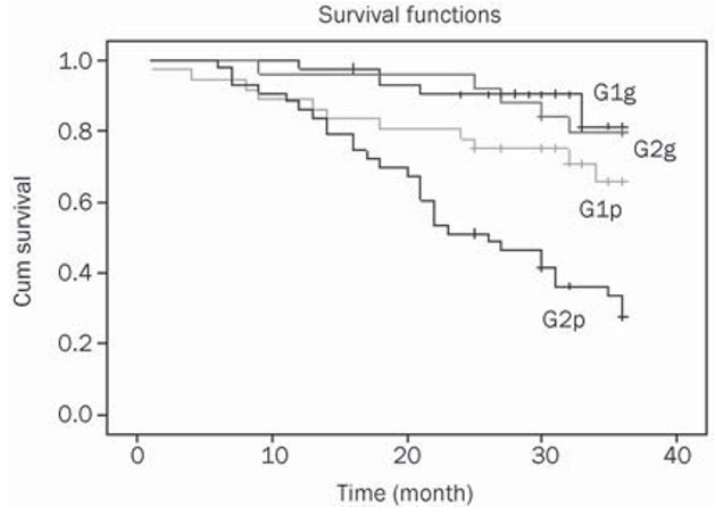

Figure 3. The overall survival rates by group.

therapy became the mainstay of treatment for men with advanced and metastatic prostate carcinoma. The initial regimen of androgen deprivation therapy included bilateral orchiectomy, estrogen therapy, or both. However, these therapies had a greatly negative impact on quality of life, not to mention the occurrence of lethal cardiac events ${ }^{[20,21]}$. The discovery of synthetic luteinizing hormone-releasing hormone agonists reduced the cardiac toxicity and the other side effects of androgen deprivation therapy. Then, in 1983 Labrie et a $l^{[9]}$ conducted a new trial for the total elimination of androgen from both the testes and adrenal glands. They reported a small series of patients with advanced prostate carcinoma managed with an LHRH analogue combined with an oral antiandrogen. The results showed an impressive improvement in survival rate, and this success led to numerous studies exploring this concept. In addition, with the longer duration of LHRH dosage intervals and the reduced negative impact to patients' selfimage and cosmetic appearance ${ }^{[7,8]}$, LHRH agonist therapy became more popular than surgical castration ${ }^{[22,23]}$.

Because medical castration is reversible and has less of a psychiatric impact than surgical castration, several new trials have been conducted in different clinical situations. These trials showed that patients with localized prostate carcinoma received no benefit from primary androgen deprivation therapy ${ }^{[24,25]}$; on the contrary, patients with metastatic prostate carcinoma showed a survival benefit with androgen deprivation therapy ${ }^{[26,27]}$. Additionally, these trials provided evidence supporting androgen deprivation therapy for a survival benefit among patients who underwent radical prostatectomy with positive lymph node resection ${ }^{[28,29]}$ and among those with locally advanced prostate carcinoma after radiotherapy ${ }^{[30,31]}$.

The medical insurance system has become more prevalent and influential in recent decades. Medical expenses surge with administration of more new drugs and the use of new and delicate medical instruments. Restriction of medical expenses became inevitable and is an important factor in physicians' decision-making processes. As a result, the number of surgical castrations increased again ${ }^{[13,14]}$. This study provides evidence supporting surgical castration rather than medical castration with LHRH, especially among patients with poor prognoses. We also showed that there was little survival benefit among patients with good prognosis scores, regardless of the method of castration. In Samson's analysis of patients with complete androgen blockade or monotherapy with LHRH, they also concluded that there was no survival benefit between complete androgen blockade and monotherapy with $\mathrm{LHRH}$ in patients with a good prognosis ${ }^{[10]}$. As a result, in the poor prognosis group ( $>5$ sites of bone metastasis, hydronephrosis, pain requiring analgesics, alkaline phosphatase $>2$ times the upper limit of the normal range), bilateral orchiectomy should be performed for a better survival benefit. The reason why surgical castration is superior to medical castration with LHRH is not clear. According to Morgentaler's saturation model, prostate carcinoma requires a fairly low testosterone concentration for the carcinoma to flourish ${ }^{[32]}$. There are some studies indicating that LHRH therapy does not achieve as low of a testosterone level as does bilateral orchiectomy ${ }^{[33-36]}$. This might be one of the reasons why surgical castration had better outcomes for advanced prostate carcinoma, especially in the poor prognosis group. Another reason that might explain this difference is the sustainability of testosterone suppression. Bilateral orchiectomy would definitely cease the production of testosterone. Owing to different pharmacokinetics from person to person, the LHRH agonist might not be able to remain effective for one full month in every single person. Then, during readministration of the LHRH agonist, testosterone flares up and this causes so-called acute-on-chronic responses ${ }^{[36]}$. In our present study, antiandrogen was used in the medical castration group, but repeated flare-up episodes might also lead to a poor result.

In this study, ADT for the treatment of advanced prostate carcinoma improved tumor progression-free survival and biochemical failure rates after 12 months for patients in the surgical castration group. When we compared Reijke scores among the patients, surgical castration for patients with poor prognostic scores resulted in better disease-free survival and PSA normalization rates. The survival advantage suggests that surgical castration is beneficial in patients with poor prognosis scores, although further studies are needed to identify which patients would derive the most benefit from hormone therapy, particularly when balanced against the potential adverse cardiovascular effects of long-term ADT.

\section{Acknowledgements}

This study was supported by research grants from Chang Gung Memorial Hospital (No CMRPD-170471 and CMRPD160131) and the National Science Council, Taiwan, China (№ 97-2320-B-182-023-MY3 and 98-2314-B-182-042-MY3).

\section{Author contribution}

Ke-hung TSUI designed research; Ke-hung TSUI, Phei-lang CHANG performed research; Yu-hsiang LIN and Chien-lun CHEN contributed new analytical tools and reagents; Chen Pang HOU analyzed data; Yu-hsiang LIN wrote the paper. 


\section{References}

1 Stamey T, Yang N, Hay A, McNeal J, Freiha F, Redwine E. Prostatespecific antigen as a serum marker for adenocarcinoma of the prostate. N Engl J Med 1987; 317: 909-16.

2 Wang MC, Valenzuela LA, Murphy GP, Chu TM. Purification of a human prostate specific antigen. Invest Urol 1979; 17: 159-63.

3 Loblaw DA, Virgo KS, Nam R, Somerfield MR, Ben-Josef E, Mendelson DS, et al. Initial hormonal management of androgen-sensitive metastatic, recurrent, or progressive prostate cancer: 2007 Update of an American Society of Clinical Oncology Practice Guideline. J Clin Oncol 2007; 25: 1596-605.

4 Huggins C, Hodges CV. Studies on prostatic cancer: I. The effect of castration, of estrogen and of androgen injection on serum phosphatases in metastatic carcinoma of the prostate. Cancer Res 1941; 1: 293-7.

5 Studer UE, Collette L, Whelan P, Albrecht W, Casselman J, de Reijke T, et al. Using PSA to guide timing of androgen deprivation in patients with T0-4 NO-2 MO prostate cancer not suitable for local curative treatment (EORTC 30891). Eur Urol 2008; 53: 941-9.

6 Studer UE, Whelan P, Albrecht W, Casselman J, de Reijke T, Hauri D, et al. Immediate or deferred androgen deprivation for patients with prostate cancer not suitable for local treatment with curative intent: European Organisation for Research and Treatment of Cancer (EORTC) Trial 30891. J Clin Oncol 2006; 24: 1868-76.

7 Anderson J, Abrahamsson PA, Crawford D, Miller K, Tombal B. Management of advanced prostate cancer: can we improve on androgen deprivation therapy? BJU Int 2008; 101: 1497-501.

8 Saylor PJ, Smith MR. Metabolic complications of androgen deprivation therapy for prostate cancer. J Urol 2009; 181: 1998-2006.

9 Labrie F, Dupont A, Belanger A, Lacoursiere Y, Raynaud JP, Husson JM, et al. New approach in the treatment of prostate cancer: complete instead of partial withdrawal of androgens. The Prostate 1983; 4: 579-94.

10 Samson DJ, Seidenfeld J, Schmitt B, Hasselblad V, Albertsen PC, Bennett CL, et al. Systematic review and meta-analysis of monotherapy compared with combined androgen blockade for patients with advanced prostate carcinoma. Cancer 2002; 95: 361-76.

11 Eisenberger MA, Blumenstein BA, Crawford ED, Miller G, McLeod DG, Loehrer PJ, et al. Bilateral orchiectomy with or without flutamide for metastatic prostate cancer. N Engl J Med 1998; 339: 1036-42.

12 Loblaw DA, Mendelson DS, Talcott JA, Virgo KS, Somerfield MR, Ben-Josef E, et al. American Society of Clinical Oncology recommendations for the initial hormonal management of androgen-sensitive metastatic, recurrent, or progressive prostate cancer. J Clin Oncol 2004; 22: 2927-41.

13 Weight CJ, Klein EA, Jones JS. Androgen deprivation falls as orchiectomy rates rise after changes in reimbursement in the US medicare population. Cancer 2008; 112: 2195-201.

14 Chodak GW. Is the increase in orchiectomy for prostate cancer patients appropriate? Cancer 2008; 112: 2106-7.

15 Morote J, Esquena S, Abascal JM, Trilla E, Cecchini L, Raventós CX, et al. Failure to maintain a suppressed level of serum testosterone during long-acting depot luteinizing hormone-releasing hormone agonist therapy in patients with advanced prostate cancer. Urol Int 2006; 77: 135-8.

16 Kaisary AV, Tyrrell CJ, Peeling WB, Griffiths K. Comparison of LHRH analogue (Zoladex) with orchiectomy in patients with metastatic prostatic carcinoma. Br J Urol 1991; 67: 502-8.

17 Bubley GJ. Is the flare phenomenon clinically significant? Urology 2001; 58: 5-9.

18 de Reijke T, Derobert E. Prognostic factor analysis in patients with advanced prostate cancer treated by castration plus anandron or placebo: a final update. Eur Urol 2002; 42: 139-46.
19 Studer UE, Whelan P, Albrecht W, Casselman J, de Reijke T, Hauri D, et al. Immediate or deferred androgen deprivation for patients with prostate cancer not suitable for local treatment with curative intent: European Organisation for Research and Treatment of Cancer (EORTC) Trial 30891. J Clin Oncol 2006; 24: 1868-76.

20 Chuang CK, Chu SH, Chiang YJ, Chun-Te Wu M, Lin MH, Wei TY, et al. Tolerability assessment of maximal androgen blockade with 50 $\mathrm{mg}$ daily of bicalutamide and castration in patients with advanced prostate cancer. Chang Gung Med J 2002; 25: 577-82.

21 Albertsen P. Androgen deprivation in prostate cancer-step by step. N Engl J Med 2009; 360: 2572-4.

22 Shahinian VB, Kuo YF, Freeman JL, Orihuela E, Goodwin JS. Increasing use of gonadotropin-releasing hormone agonists for the treatment of localized prostate carcinoma. Cancer 2005; 103: 1615-24.

23 Barry MJ, Delorenzo MA, Walker-Corkery ES, Lucas FL, Wennberg DC. The rising prevalence of androgen deprivation among older American men since the advent of prostate-specific antigen testing: a population-based cohort study. BJU Int 2006; 98: 973-8.

24 Wong YN, Freedland SJ, Egleston B, Vapiwala N, Uzzo R, Armstrong K. The role of primary androgen deprivation therapy in localized prostate cancer. Eur Urol 2009; 56: 609-16.

25 Lu-Yao GL, Albertsen PC, Moore DF, Shih W, Lin Y, DiPaola RS, et al. Survival following primary androgen deprivation therapy among men with localized prostate cancer. JAMA 2008; 300: 173-81.

26 Diblasio CJ, Malcolm JB, Hammett J, Wan JY, Aleman MA, Patterson $A L$, et al. Survival outcomes in men receiving androgen-deprivation therapy as primary or salvage treatment for localized or advanced prostate cancer: 20-year single-centre experience. BJU Int 2009; 104: 1208-14.

27 Keating NL, O'Malley AJ, McNaughton-Collins M, Oh WK, Smith MR. Use of androgen deprivation therapy for metastatic prostate cancer in older men. BJU Int 2008; 101: 1077-83.

28 Messing EM, Manola J, Yao J, Kiernan M, Crawford D, Wilding G, et al. Immediate versus deferred androgen deprivation treatment in patients with node-positive prostate cancer after radical prostatectomy and pelvic lymphadenectomy. Lancet Oncol 2006; 7: 472-9.

29 Messing EM, Manola J, Sarosdy M, Wilding G, Crawford ED, Trump D. Immediate hormonal therapy compared with observation after radical prostatectomy and pelvic lymphadenectomy in men with node-positive prostate cancer. N Engl J Med 1999; 341: 1781-8.

30 Bolla M, Gonzalez D, Warde P, Dubois JB, Mirimanoff RO, Storme G, et al. Improved survival in patients with locally advanced prostate cancer treated with radiotherapy and goserelin. N Engl J Med 1997; 337: 295-300.

31 D'Amico AV, Manola J, Loffredo M, Renshaw AA, DellaCroce A, Kantoff PW. 6-Month androgen suppression plus radiation therapy vs radiation therapy alone for patients with clinically localized prostate cancer: a randomized controlled trial. JAMA 2004; 292: 821-7.

32 Morgentaler A, Traish AM. Shifting the paradigm of testosterone and prostate cancer: the saturation model and the limits of androgendependent growth. Eur Urol 2009; 55: 310-20.

33 Oefelein MG, Cornum R. Failure to achieve castrate levels of testosterone during luteinizing hormone releasing hormone agonist therapy: the case for monitoring serum testosterone and a treatment decision algorithm. J Urol 2000; 164: 726-9.

34 Yri OE, Bjoro T, Fossa SD. Failure to achieve castration levels in patients using leuprolide acetate in locally advanced prostate cancer. Eur Urol 2006; 49: 54-8; discussion 58.

35 Tombal B. The importance of testosterone control in prostate cancer. Eur Urol Suppl 2007; 6: 834-9.

36 Tombal B, Berges R. How good do current Ihrh agonists control testosterone? Can this be improved with Eligard ${ }^{\circledR}$ ? Eur Urol Suppl 2005; 4: 30-6. 